\title{
Recovery of Platinum and Palladium Ions from Aqueous Solution Using Grape Stalk Waste
}

\author{
A. Mavhungu, R. K. K. Mbaya, and M. L. Moropeng
}

\begin{abstract}
Platinum and palladium were adsorbed onto grape stalk and activated grape stalk prepared by chemical activation process using phosphoric acid. The amount of platinum and palladium uptake (adsorbent loading) was quantified. Influence of contact time, $\mathrm{pH}$ were investigated. The results showed that the adsorption of metal ions is $\mathrm{pH}$ dependent. The presence of base metal ions in the solution did not affect the process of adsorption of palladium and platinum. Effect of temperature was taken into account during the determination of isotherms. Langmuir and Freundlich isotherm models were applied and compared.
\end{abstract}

Index Terms-Adsorption, chemical activation, grape stalk, base metals.

\section{INTRODUCTION}

The platinum group metals (PGMs) are precious metals, which comprise of palladium $(\mathrm{Pd})$, platinum $(\mathrm{Pt})$, rhodium $(\mathrm{Rd})$, iridium (Ir), ruthenium $(\mathrm{Ru})$, and osmium (Os). They are available at low concentration in the earth crust. They occur in minerals in close association with one another, and with other transition-metal sulfides and selenides; especially nickel, cobalt, and copper sulfides. Platinum and palladium have the greatest economic importance and are found in the largest quantities. The other four PGMs are produced only as co-products of platinum and palladium [1].

They are widely used in many fields such as catalysts in various chemical processes, electrical and electronic industries, corrosion resistant materials, and jewelry due to their specific physical and chemical properties. Their increased use in automobile exhaust emission control catalyst has led to a dramatic increase in their demand [1]-[3]. The recovery and separation of PGMs from primary and secondary sources are considered a strategic solution to the high demand of these metals for industrial applications and their increasing scarcity.

Due to their importance and high price, it is essential to develop efficient recovery methods for these elements [4].

Many studies focused on the extraction and separation of PGM have been done [3], [5]. Solvent extraction, ion exchange, membrane separation and adsorption have been developed for the recovery of platinum and palladium from aqueous solution, [6]. However, adsorption had been proven to be an effective approach for recovery of platinum and palladium from dilute solutions [7]-[11].

Manuscript received July 10, 2013; revised September 22, 2013. This work was supported in part by Tshwane University of Technology and South Africa National Research Foundation.

The authors are with the Department of Chemical, Metallurgical and Material Engineering, Tshwane University of Technology, South Africa (email: funani.mavhungu@yahoo.com, mbayar@tut.ac.za, moropengl@tut.ac.za).
Activated carbon and different types of ion-exchange resins are often used in the adsorption processes, because it has higher specific surface areas and active functional group. They are recommended for the recovery of metal ions although they are not selective [12]. However, their high price and regeneration costs have encouraged researcher to look for low cost materials for the adsorption of precious metals [13].

In recent years, research has been focused on low cost adsorbents for the removal and recovery of PGMs ions in solutions. Agricultural material contains proteins, polysaccharides and lignin which are associated with functional groups responsible for metal ion adsorption. The abundant natural occurrence and presence of large amount of surface functional groups make various agricultural wastes good alternatives synthetic adsorbents [14].

Grape stalk wastes are currently not fully utilized are discharged as waste, but can possibly be used as adsorbent of PGMs and an alternative precursor for porous carbon. It has been found to have potential as an in expensive adsorbent in the development of efficient, clean and cheap technology. It has been satisfactorily applied in the adsorption of heavy metals such as copper [15], nickel and copper [16]-18], lead and cadmium [19], chromium, [20].

The adsorption of metals by these kinds of materials might be attributed to their proteins, carbohydrates, and phenolic compounds that have carboxyl, hydroxyl, sulphate, phosphate, and amino groups that can bind metal ions. It has been reported that adsorption of metal ions onto grape stalks released an equivalent amount of alkaline and alkaline earth metals $(\mathrm{K}+, \mathrm{Mg} 2+$, and $\mathrm{Ca} 2+)$ as well as protons, indicating that ionic exchange is predominant process responsible for metal ion uptake [21].

In this study we aim to evaluate the performance of the grape stalk in adsorption of PGMs from aqueous solutions. Effect of $\mathrm{pH}$ on adsorption, adsorbent dosage, Kinetics and maximum capacity in grape stalk wastes before and after chemical activation will be quantified, and comparisons between both adsorbents performance will be established. The possibility of metal recovery by desorption will be also analyzed.

\section{EXPERIMENTAL}

\section{A. Material and Solution}

Grape stalk used in this study was found at Tshwane market in Pretoria (SA). It was rinsed several times with hot water, three times with cold distilled water. Then oven dried at $383 \mathrm{~K}$ until it reached constant weight, and finally cut into small chips. Metal solution was prepared by mixing appropriate amounts of PGMs standard solution $(20 \mathrm{mg} / \mathrm{L})$ 
with distilled water in a $5 \mathrm{~L}$ volumetric flask. The solution was stored in a $5 \mathrm{~L}$ volumetric flask with a glass stopper. Working standards were prepared by dilution of the stock solution. Analytical grade reagents from Merck's, $\mathrm{H}_{3} \mathrm{PO} 4$ (85wt\% purity), $\mathrm{NaOH}$ (97 wt\% purity) and HCL (38wt\% purity) were used.

\section{B. Chemical Activation}

Chemical activation assay were carried out using raw grape stalk as received. Grape stalk sample were impregnated with orthophosphoric acid and afforded to soak for $24 \mathrm{hrs}$. Then, they were drained and oven dried at $383 \mathrm{~K}$ for $24 \mathrm{hrs}$. the dried samples were thermally treated in a furnace at $783 \mathrm{~K}$ in the absence of oxygen for $1 \mathrm{hr}$. the activated carbon obtain were washed with distilled water until neutrality and oven dried for $24 \mathrm{hrs}$ [22].

\section{Batch Adsorption Experiment}

Adsorption experiments were performed by putting into contact a fixed amount of dry grape stalk and produced activated carbon with PGMs rich solution of $100 \mathrm{ml}$ plastic bottles. It was placed in a shaker and shaken for $24 \mathrm{hrs}$ at a room temperature. Solution $\mathrm{pH}$ was noted $(\mathrm{pH}=1)$. After contact for desired time, the samples were filtered and the filtrate was then analyzed for residual PGMs concentration using Inductively Coupled Plasma-Spectra Arcos (ICP).

The amount of adsorbed metal, $q$ was calculated by the mass balance of the metals before and after adsorption, as shown by these equations below.

$$
q_{e}=\left(C_{i}-C_{e}\right) \frac{V}{w}
$$

And the equation

$$
M e=\left(\frac{C_{i}-C_{e}}{C_{i}}\right) \times 100
$$

where $C_{i}$ is the initial metal ion concentration $(\mathrm{mg} / \mathrm{L}), C_{e}$ is metal ion concentration in the aqueous solution $(\mathrm{mg} / \mathrm{L}) ; \mathrm{V}$ is volume of aqueous phase $(\mathrm{ml})$ and $\mathrm{w}$, weight of the adsorbents (grape stalk and activated grape stalk) in gram $(\mathrm{g})$.

\section{Effect of Contact Time}

Effect of contact time on PGMs adsorption onto grape stalk and produced AC was done by using $200 \mathrm{ml}$ of a solution in $200 \mathrm{ml}$ sample bottle. The mass of both the adsorbents was $0.3 \mathrm{~g}$ and $\mathrm{pH}$ of the solution was adjusted to 1 . $10 \mathrm{ml}$ were collected after time interval. The solution was shaken at $200 \mathrm{rpm}$ at room temperature, $298 \mathrm{~K}$ for $24 \mathrm{hrs}$.

\section{E. Effect of Adsorbent Dose}

Effect of adsorbent dose on adsorption of PGM metal ion from aqueous solution was studied by adding $30 \mathrm{ml}$ of aqueous solution contains $10 \mathrm{mg} / \mathrm{L}$ of $\mathrm{Pt}, \mathrm{Pd}, \mathrm{Cu}, \mathrm{Fe}$, and $\mathrm{Co}$ in $100 \mathrm{ml}$ plastic bottles. The $\mathrm{pH}$ was adjusted to $1 \mathrm{using} \mathrm{HCl}$ solution. Adsorbent dose was varied from $0.1 \mathrm{~g}$ to $0.8 \mathrm{~g}$ and the mixture was shaken for $24 \mathrm{hrs}$ at room temperature, $298 \mathrm{~K}$.

\section{F. Effect of $p H$}

The $\mathrm{pH}$ of the metal solutions has been identified as the most important variable controlling adsorption on hydrous solids. This is partly due to the fact that hydrogen ions are strong competing adsorbents and partly that the solution $\mathrm{pH}$ influences the chemical speciation of metal ions [18].

Effect of $\mathrm{pH}$ on the adsorption was studied by adjusting the initial solution $\mathrm{pH}$ within the range of $0.1-3.5$. In these experiments initial metal concentration was $10 \mathrm{mg} / \mathrm{L}$ for platinum and palladium.

\section{G. Adsorption Isotherms}

The effect of initial concentration of the metal ion on the uptake by adsorbent was carried out by placing $0.3 \mathrm{~g}$ adsorbent in a series of $100 \mathrm{~mL}$ plastic bottles containing $30 \mathrm{~mL}$ of metal ions. Metal ion concentration was varied from $10 \mathrm{mg} / \mathrm{L}$ to $60 \mathrm{mg} / \mathrm{L}$ and $\mathrm{pH} 1$. The plastic bottles were agitated on a shaker at 200rpm for $24 \mathrm{hrs}$ while keeping the temperature, $T$ at 298,308 , and $318 \mathrm{~K}$.

\section{RESUlTS AND DisCUSSIONS}

\section{A. Effect of Adsorbent Dose}

The dosage of an adsorbent is a factor which is known to strongly influence the extent of adsorption equilibrium. The effect of adsorbent dosage on the percentage metal removal of platinum and palladium from aqueous solution with grape stalk, activated grape stalk was studied and is presented graphically on Fig. 1 and Fig. 2. From Fig. 1, it is clear that the removal of platinum from aqueous solution increased with increase adsorbent mass from around 50 to $93 \%$ for 0.1 to $0.3 \mathrm{~g}$ and from 50 to $100 \%$ for 0.1 to $0.2 \mathrm{~g}$ of palladium respectively. In Fig. 2, increase adsorption mass from around 65 to $100 \%$ for 0.1 to $0.5 \mathrm{~g}$ platinum removal and for palladium was constant $100 \%$ from 0.1 to $0.8 \mathrm{~g}$. The percentage increase in platinum and palladium removal with increase in adsorbent mass for a fixed initial platinum and palladium concentration is due to increase in adsorption sites of the adsorbent. Grape stalk and activated grape stalk were selective on the adsorption of platinum and palladium in the presence of some heavy metals.

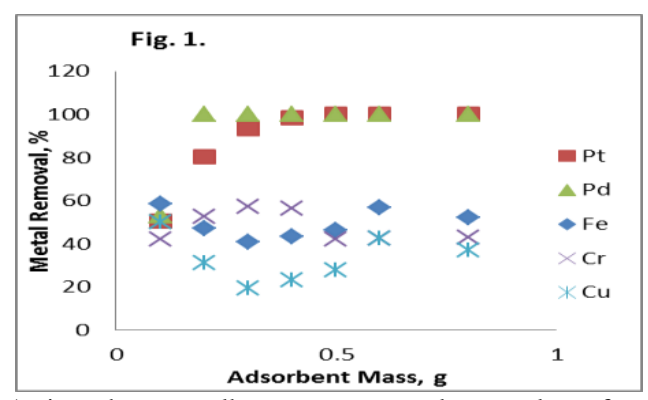

Fig. 1. Activated grape stalk; percentage metal removal as a function of adsorbent mass.

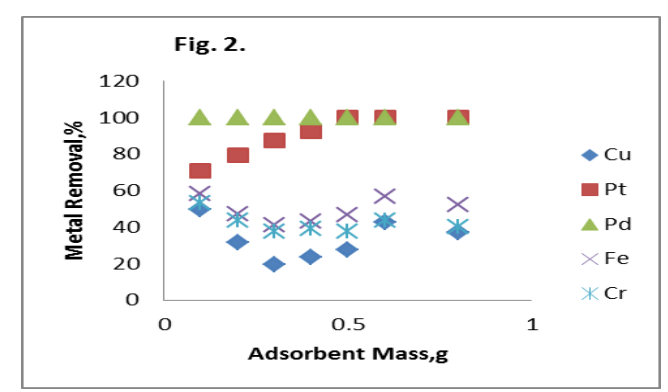

Fig. 2. Grape stalk: Percentage metal removal as a function of adsorbent mass.

\section{B. Effect of $p H$}

The $\mathrm{pH}$ value of aqueous solutions plays an important role 
in the whole adsorption process. In this study, the effect of initial $\mathrm{pH}$ on adsorption capacity of platinum and palladium onto grape stalk and activated grape stalk was studied in the range of 0.5 to 4 at $10 \mathrm{mg} / \mathrm{L}$ initial platinum and palladium solution concentration and it is shown on Fig. 3 and Fig. 4. From the study, the adsorption of platinum and palladium is highly $\mathrm{pH}$ dependent

The removal of platinum and palladium was found to be in acidic range, which is $\mathrm{pH} 1.5$, with the maximum uptake of 1.5 and $1.4 \mathrm{mg} / \mathrm{g}$ for platinum and palladium respectively and then, the uptake declined significantly, Fig. 3. In Fig. 4, the data indicated that the was no adsorption capacity increase palladium removal onto activated grape stalk and incase of platinum, adsorption capacity slightly changed between $\mathrm{pH}$ 0.5 and 1.0, later it decreased drastically at a $\mathrm{pH}$ 2.2. At higher $\mathrm{pH}$ values the adsorption capacity decreases, this may be explained by the presence of less absorbable platinum and palladium species because of the lower availability of chloride anions. Higher uptakes obtained at lower $\mathrm{pH}$ may be due to the electrostatic attractions between negatively charged functional groups located on the reactive platinum and platinum and positively charged adsorbent surface. Hydrogen ion also acts as a bridging ligand between the adsorbent wall and palladium, platinum molecules.

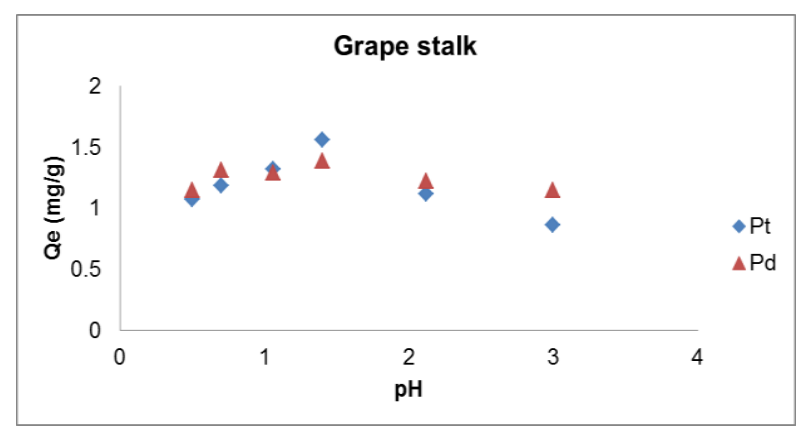

Fig. 3. Grape stalk and Fig. 4 activated grape stalk; adsorption capacity, $Q e$ as a function of solution $\mathrm{pH}$.

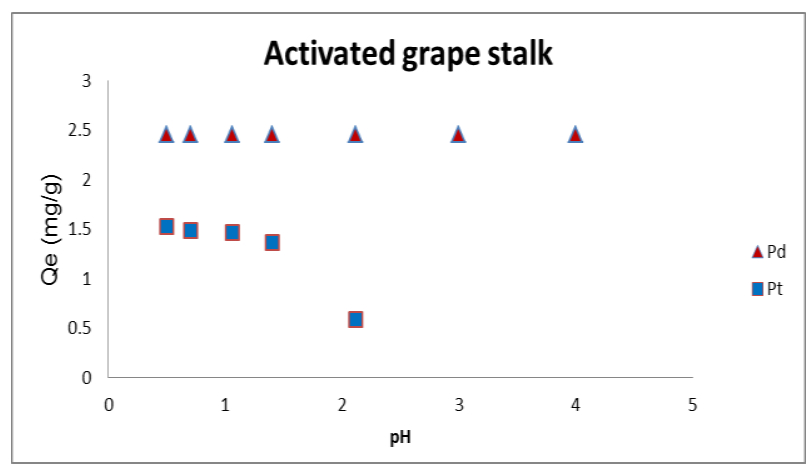

Fig. 4. Activated grape stalk; adsorption capacity, $Q e$ as a function of solution $\mathrm{pH}$.

\section{Isotherms}

Adsorption isotherms are a basic requirement for the design of an adsorption system. The adsorption equilibrium data were fitted for the Langmuir and Freundlich isotherms. The Langmuir model represents one of the first theoretical treatments of nonlinear adsorption and suggests the uptake occurs on a homogeneous surface by monolayer adsorption without interaction between adsorbed molecules [23]. The expression of the Langmuir model is:

$$
Q_{e}=\frac{q_{m K_{L} C_{e}}}{1+K_{L} C_{e}}
$$

where $Q_{e}$ is the amount of platinum and palladium adsorbed $(\mathrm{mg} / \mathrm{g})$ at equilibrium; $C_{e}$ is the concentration of platinum and palladium at equilibrium; $K_{L}$ represents the Langmuir constant $(\mathrm{L} / \mathrm{mg})$ that relates to the affinity of binding sites and $\mathrm{q}_{\mathrm{m}}$ is the theoretical saturation adsorption capacity of the monolayer $(\mathrm{mg} / \mathrm{g})$. Equilibrium parameter, $R_{L}$, was calculated to identify whether an adsorption system is favorable or unfavorable.

$$
R_{L}=\frac{1}{1+K_{L} C_{O}}
$$

where $K_{L}$ is the Langmuir constant and $C_{o}$ is the initial concentration $\left(\mathrm{mg} / \mathrm{g}\right.$ ), the $R_{L}$ values between 0 and 1 indicate favorable adsorption. $R_{L}$ values are presented in Table I.

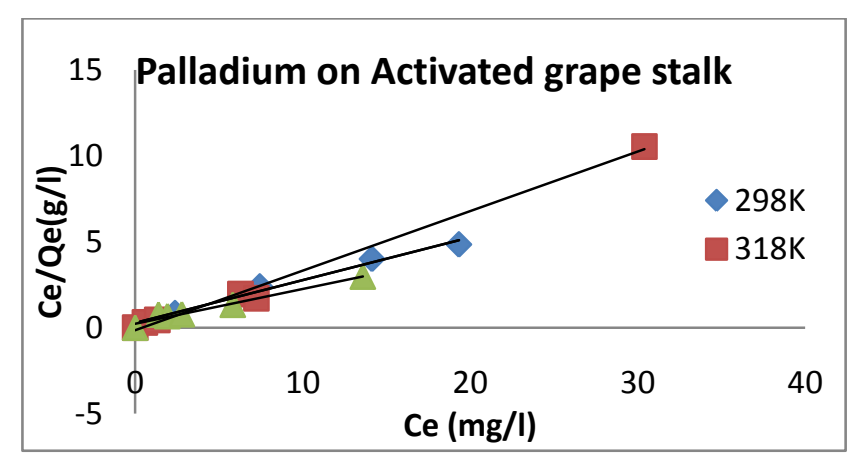

Fig. 5. Linearized isotherm, $C_{e} / Q_{e}$ as a function of $C_{e}$

The straight lines were found by plotting $C_{e} / Q_{e}$ vs. $C_{e}$, as shown in Fig. 5 up to Fig. 8, which gives the values of $q_{\max }$ and $K_{L}$. The $q_{\max }$ is not increases with increasing temperature. Langmuir isotherm parameters are shown in Table I. $R^{2}$ values found, shows that this result of Langmuir model was favorable to describe the relationship between the adsorbed amount of platinum and palladium and its equilibrium concentration.

\section{Freundlich Isotherm}

The Freundlich model assumes heterogeneous adsorption due to the diversity of the adsorption sites or the diverse nature of the metal ions adsorbed, free or hydrolysed species. The Freundlich model is expressed as:

$$
q_{e}=k_{f} C_{e}^{1 / n}
$$

where $k_{f}$ is the Freunlich constant related to adsorption capacity of adsorbent and $n$ is the Freundlich exponent related to adsorption intensity. $K_{f}$ and $1 / n$ can be calculated from the slope and intercept of the linear plot of $\log Q_{e}$ versus $\log C_{e}$.

The linearised Freundlich isotherm plot shown in Fig. 8 and 9. Table II shows the cofficients of Freundlich isotherm along with regression coefficients $\left(R^{2}\right)$. Kf were found to be 1.89 and $1.03,1 / n$ was 0.44 and 0.58 for platinum onto activated grape stalk and grape stalk respectively. For palladium onto activated grape stalk and grape stalk, $K_{f}$ was found to be 1.62 for both adsorbents and $1 / n$ was 0.46 and 0.56 respectively. $1 / n$ value between 0 and 1 indicates that the adsorption was favourable at studied conditions [23]. $R^{2}$ 
values were found to be $0.95,0.89,0.96,0.98$ which shows that this result of Freundlich model was not able to describe the relationship between the adsorbed amount of platinum and palladium and its equilibrium concentrarion.

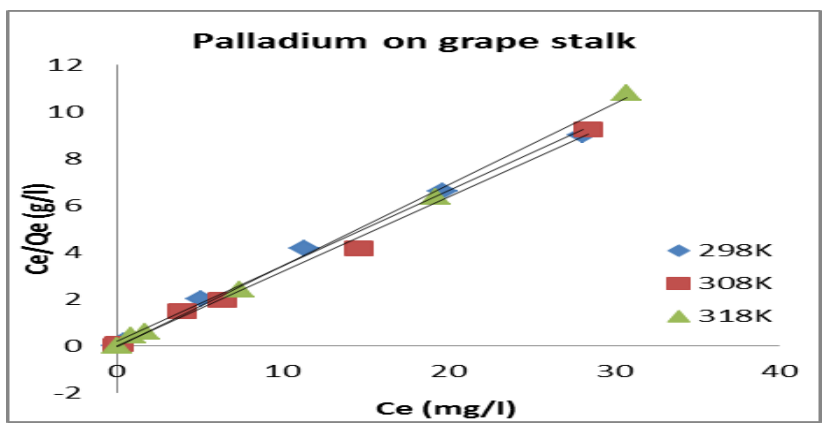

Fig. 6. Linearized isotherm, $\mathrm{Ce} / \mathrm{Qe}$ as a function of $\mathrm{Ce}$

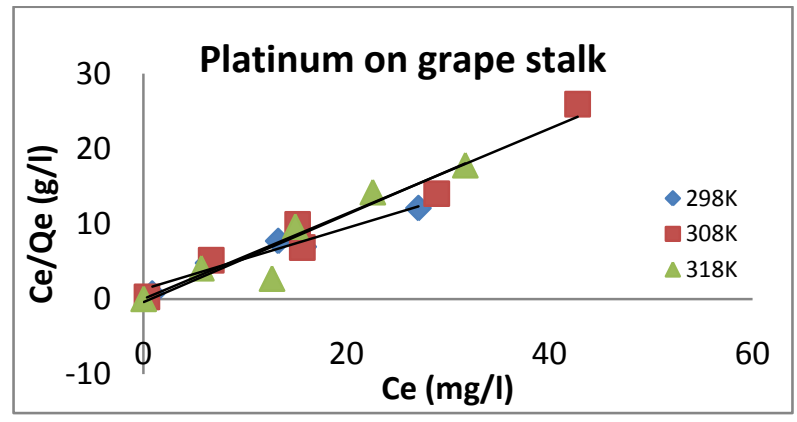

Fig. 7. Linearized isotherm, $\mathrm{Ce} / \mathrm{Q} e$ as a function of $\mathrm{Ce}$

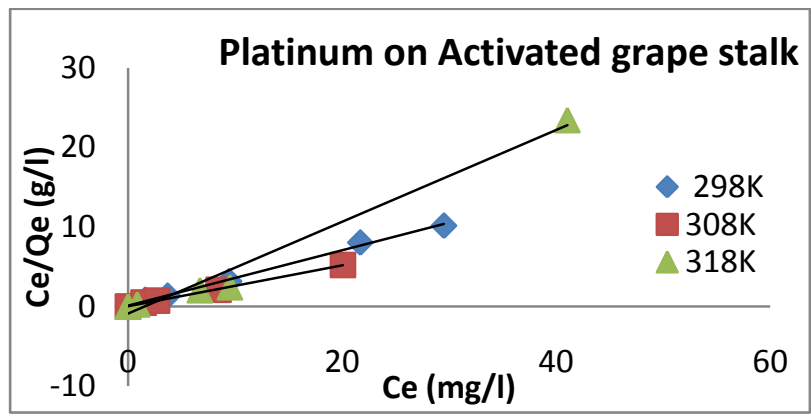

Fig. 8. Linearized isotherm, $\mathrm{Ce} / \mathrm{Q} e$ as a function of $\mathrm{Ce}$

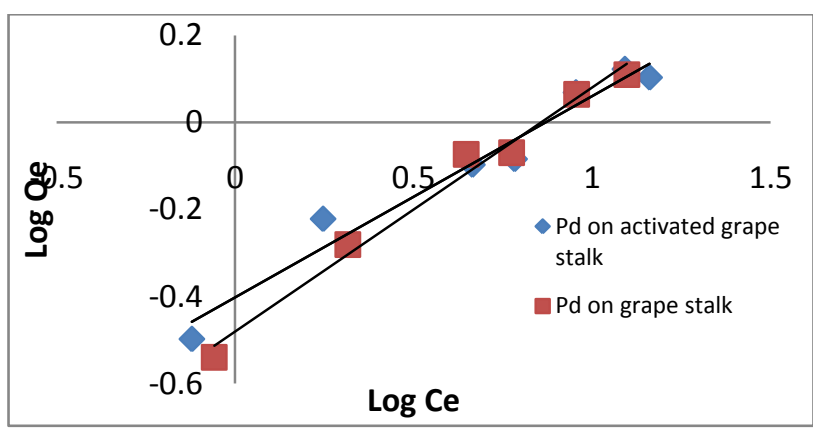

Fig. 9. $\log Q e$ as a function of $\log C e$.

\section{E. Effect of Contact Time}

Fig. 10 and Fig. 11 shows the effect of contact time as a function of adsorption capacity of $\mathrm{Pt}$ and $\mathrm{Pd}$ by grape stalk and activated grape stalk. The results show that the adsorption for both metal ions is rapid. The maximum adsorption for $\mathrm{Pt}$ and $\mathrm{Pd}$ is attained in $60 \mathrm{~min}$ for adsorbents, Fig. 10 and Fig. 11. The contact time $4 \mathrm{~h}$ was found to be sufficient to reach equilibrium.

TABLE I: FREUNDLICH PARAMETERS FOR PLATINUM AND PALLADIUM

\begin{tabular}{lllll}
\hline \hline Elements & Adsorbents & $\mathrm{R}^{2}$ & $\mathrm{~K}_{\mathrm{f}}$ & $1 / \mathrm{n}$ \\
\hline \hline platinum & $\begin{array}{l}\text { Activated grape } \\
\text { stalk }\end{array}$ & 0.9599 & 1.89 & 0.4447 \\
Grape stalk & 0.898 & 1.03 & 0.5763 \\
palladium & $\begin{array}{l}\text { Activated grape } \\
\text { stalk } \\
\text { Gape stalk }\end{array}$ & 0.965 & 1.62 & 0.4625 \\
\hline \hline
\end{tabular}

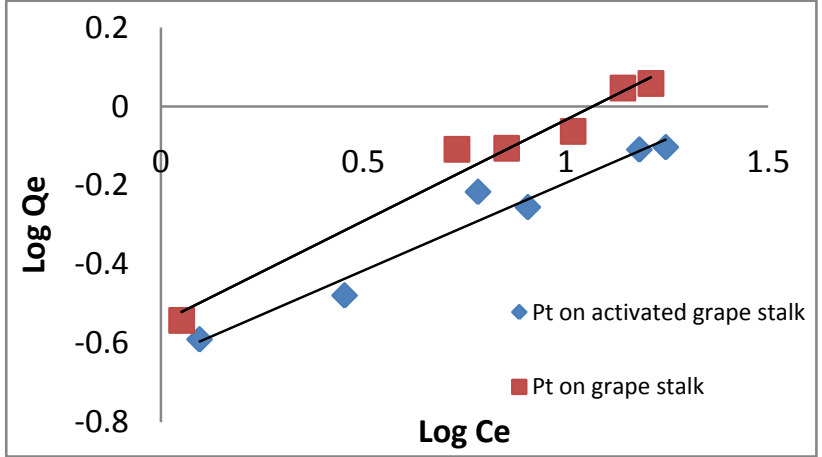

Fig. 10. $\log Q e$ as a function of $\log C e$.

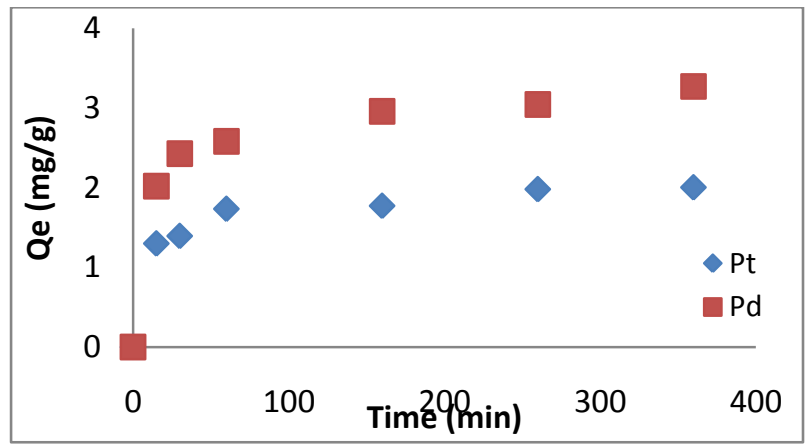

Fig. 10. Pt and Pd onto grape stalk: adsorption capacity, $Q_{e}$ as a function of time.

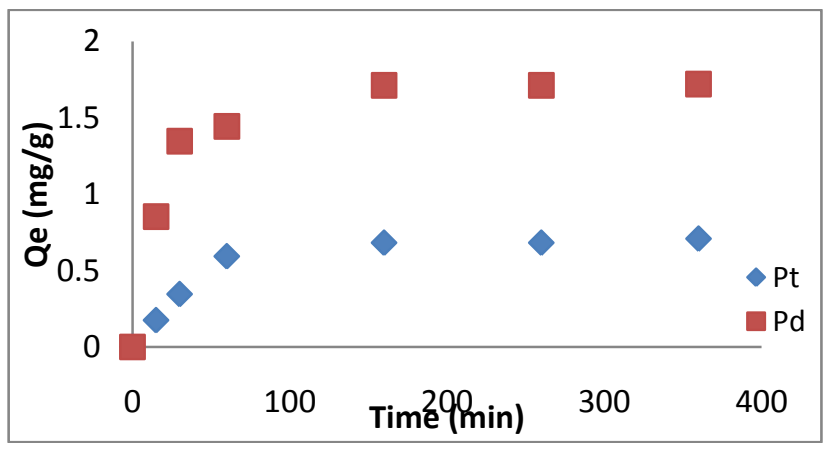

Fig. 11. Pt and Pd onto activated grape stalk: Adsorption capacity, $Q e$ as a function of time.

\section{CONCLUSION}

This study has shown that grape stalk waste and activated grape stalk is capable of effectively removing platinum and palladium ions from aqueous solution at low concentration by an ion exchange process. Adsorption of metal ions is $\mathrm{pH}$ dependent and maximum value is found at $\mathrm{pH}, 1.5$ for both metals. Platinum and palladium adsorption increased when $\mathrm{Cl}^{-}$was added as $\mathrm{HCl}$ and decreased when $\mathrm{NaOH}$ was added. The experimental data fitted well the Langmuir isotherm for 
both palladium and platinum.

The adsorption of the grape stalk and activated grape stalk with phosphoric acid to platinum and palladium successful show the practical use of this adsorbent for the separation of PGMs from aqueous metal ions solution.

\section{ACKNOWLEDGMENT}

The authors wish to express their gratitude to Tshwane University of Technology and South Africa's National Research Foundation for the financial assistance offered to make this work of a success.

\section{REFERENCES}

[1] J. Park, S. W. Won, J. Mao, I. S. Kwak, and Y. S. Yun, "Recovery of $\mathrm{Pd}$ (II) from hydrochloric solution using polyallydiamine hydrochloride modified Escherichia coli biomass," Journal of Hazardous Materials, vol. 181, pp. 794-800, May 2010.

[2] J. Kramer, W. L. Driessen, K. R. Koch, and J. Reedijk, "Highly selective extraction of platinum group metals with silica-based (poly) amine ion exchangers applied to the industrial metal refinery effluents," Hydrometallurgy, vol. 64, pp. 59-68, February 2002.

[3] L. Peng, L. Guang-Feng, C. Da-Lin, C. Shaoyi, and T. Ning, "Adsorption properties of $\mathrm{Ag}$ (I), Au (II), Pd (II) and Pt (IV) ions on commercial 717 anion exchange resin," Nonferrous Metals Society of China, vol. 19, pp. 1509-1513, September 2009.

[4] A. Uheida, Y. Zhang, and M. Muhammed, "Extraction of platinum (IV) with nonylthiourea dissolved in chloroform from hydrochloric acid media," Solvent Extraction and Ion Exchange, vol. 21, no. 6, pp. 827-840, 2003.

[5] H. Kasaini and R. Mbaya, "Continuous adsorption of Pt ions in a batch reactor and packed-bed column," Hydrometallurgy, vol. 97, pp. 111-118, February 2009.

[6] R. Wang, X. Liao, and B. Shi, “Adsorption behaviors of Pt (II) and Pd (II) On collagen fiber immobilized bayberry tannin," Ind. Eng. Chem. Res., vol. 44, no. 12, pp. 4221-4226, May 2005.

[7] J. Chen and K. Huang. A new technique of platinum group metals by pressure cyanidation. Hydrometallurgy, 82, pp. 164-171, April 2006.

[8] H. Ma, X. Liao, X. Liu, and B. Shi, "Recovery of platinum (IV) and palladium (II) by bayberry tannin immobilized collagen fiber membrane from water solution," Journal of Membrane Science, vol. 278, pp. 373-380, December 2005.

[9] C. Mack, B. Wilhelmi, J. R. Duncan, and J. E. Burgess, "Biosorption of precious metals," Biotechnology Advances, vol. 25, pp. 264-271, January 2007.

[10] A. Ramesh, H. Hasegawa, W. Sugimoto, T. Maki, and K. Ueda, "Adsorption of gold (III), platinum (IV), and palladium (II) onto glycine modified cross linked with chitosan resin," Bioresource Technology, vol. 99, pp. 3801-3809, August 2007.

[11] L. Zhou, J. Liu, and Z. Liu, "Adsorption of platinum (IV) and palladium from aqueous solution by Thiourea-modified chitosan microspheres," Hazardous Materials, vol. 172, pp. 439-446, July 2009.

[12] S. A. Dastgheid and D. A. Rockstraw, "A model for the adsorption of single metal ion solutes in aqueous solution onto activated carbon produced from pecan shell," Pergamon, Carbon 1, 2002

[13] M. Martinez, N. Miralles, S. Hidalgo, N. Fiol, I. Villaescusa, and J. Poch, "Removal of lead (II) and Cadmium (II) from aqueous solutions using grape stalk waste," Journal of Hazardous Materials, vol. B133, pp. 203-211, November 2005.

[14] K. M. Shareef, "Sorbents for contaminants uptake from aqueous solutions. Part I: Heavy metals," World Journal of Agricultural Sciences, vol. 5(S), pp. 819-831, 2009.

[15] A. Florido, C. Valderrama, J. A. Arévalo, A. Casas, M. Martínez, and N. Miralles, "Application of two sites non-equilibrium sorption model for the removal of $\mathrm{Cu}$ (II) onto grape stalk wastes in a fixed-bed column," Chemical Engineering Journal, vol. 156, pp. 298-304, October 2009.

[16] C. Escudero, C. Gabaldon, P. Marzal, and I. Villaescusa, "Effect of EDTA on divalent metal adsorption onto grape stalk and Exhaust coffee wastes," Journal of Hazardous Materials, vol. 152, pp. 476-485, July 2007.

[17] C. Valderrama, J. A. Arevalo, I. Casas, M. Martinez, N. Miralles, and A. Florid, "Modeling of the Ni (II) removal from aqueous solutions onto grape stalk wastes in fixed-bed column," Hazardous Materials, 174, pp. 144-150, September 2009.
[18] I. Villaescusa, N. Fiol, M. Martinez, N. Miralles, J. Poch, and J. Serarols, "Removal of copper and nickel ions from aqueous solutions by grape stalk wastes," Water Research, vol. 38, pp. 992-1002, October 2003

[19] N. Miralles, M. Martinez, A. Florido, I. Casas, N. Fiol, and I. Villaescusa, "Grape stalks waste as low cost Biosorbents: An alternative for metal removal from aqueous solutions," Extraction and Ion Exchange, vol. 26, pp. 261-270, 2008.

[20] C. Escudero, N. Fiol, and I. Villaescusa, "Chromium sorption on grape stalks encapsulated in calcium beads," Environmental Chem. Lett., vol. 4, pp. 239-242, June 2006.

[21] N. Miralles, C. Valderrama, I. Casas, M. Martinez, and A. Florido, "Cadmium and lead removal from aqueous solution by grape stalk waste: Modeling of a fixed bed column," Journal of Chemical Engineering, vol. 55, pp. 3548-3554, May 2010.

[22] A. C. Deiana, M. F. Sardella, H. Silva, A. Amaya, and N. Tancredi, "Use of grape stalk, a waste of the viticulture industry, to obtain activated carbon," Journal of Hazardous Materials, vol. 172, pp. 13-19, June 2009

[23] A. Sari, D. Mendi, M. Tuzen, and M. Soylak, "Biosorption of palladium (II) from aqueous solution by moss (Racomitrium lanuginosum) biomass: Equilibrium, kinetic and thermodynamic studies," Journal of Hazardous Materials, vol. 162, pp. 874-879, May 2009.

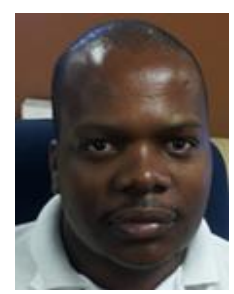

Avhafunani Mavhungu was born at Gondeni Village, Limpopo province, South Africa on May 20, 1980. He has got his bachelor degree BTech Chemical Engineering in 2009 from Tshwane University of Technology, Pretoria, South Africa. $\mathrm{He}$ is presently a master's student at the same institute. He has experience in water purification/treatment and Gold production. He's currently a part time process technologist trainee at Mott MacDonald PDNA, Johannesburg, South Africa. Mr. Mavhungu is currently registered with Engineering Council of South Africa (ECSA), Institute of Chemical Engineers (SAICHE), and also a member of International Association of Engineers (IAENG).

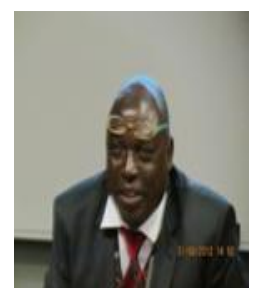

Kadiambuji Kady Richard Mbaya is a sincere, motivated and committed individual with a bachelor degree in chemical engineering from University of Lubumbashi (DR Congo), a master degree in chemical engineer and a doctorate degree in the same field at Tshwane University of Technology (RSA). Majors in the following fields: mineral beneficiation, hydrometallurgy, separation technologies, mine water and waste treatment. His exceptional, expertise in these fields cited above, strategic management, staff management and technical skills were tested and strengthened whilst working as process engineer for four years in a big mining company Sodimiza in DR Congo, six years as business development manager at international business engineering consultants dealing also with import \& export of mineral processing equipment's, eleven years as lecturer at postgraduate and under graduate level, supervising $\mathrm{PhD}, \mathrm{M}$ Tech and $\mathrm{B}$ Tech students projects at Tshwane University of Technology, Pretoria-South Africa in the Department of Chemical and Metallurgical Engineering. $\mathrm{He}$ was chairman of one the session of nickel Processing '12, Mineral Engineering International (MEI) (13 to 15 November 2012, Cape Town). He was representing South Africa in research collaboration between Tshwane University of Technology and University of Boras (Sweden) on the project "Application of scientific computational tools in the design and development of selective adsorbents for water treatment and metal separation". The project was funded by the National Research Foundation (NRF) and the Swedish Development Cooperation Agency (SIDA).

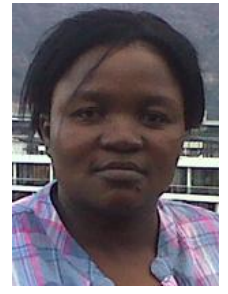

Mapula Lucey Moropeng is a lecture at Chemical, Metallurgy and Material Engineering Department, Tshwane University of Technology. She has a Bachelor degree in Chemical Engineering from Tshwane University of Technology. Mapula Lucey received her Masters degree in Chemical Engineering and now a DTech student in the same field at Tshwane University of Technology. Her area of interest included modelling and similation nano particles, and

Hydrometallurgy. 